\title{
リブ付き内部流路によるガスタービン冷却動翼の連成伝熱解析*
}

\author{
高 橋 俊 彦*1, 渡 辺 和 徳*1, 酒 井 高 行*1
}

\section{Conjugate Heat Transfer Calculation of a Gas Turbine Rotor Blade with Ribbed Internal Cooling Passages}

\author{
Toshihiko TAKAHASHI ${ }^{* 2}$, Kazunori WATANABE and Takayuki SAKAI \\ ${ }^{* 2}$ Central Research Institute of Electric Power Industry, \\ 2-6-1 Nagasaka, Yokosuka-shi, Kanagawa, 240-0196 Japan
}

\begin{abstract}
The present paper reports on numerical prediction of temperature distribution of the rotor blade in a gas turbine, which has ribbed serpentine passages for internal cooling. The three-dimensional numerical analysis was conducted by thermal conjugation of inside and outside fields of the blade, which consists of convection heat transfer around the blade, thermal conduction in the blade material and internal cooling. Correlations of heat and mass transfer in ribbed channels were applied to evaluate heat transfer rate of the internal cooling. The predicted blade temperature profile for the rating condition coincides with the distinctive features of damage on an actual blade. And that profile is in agreement with local temperature estimated by destructive test of the blade. Moreover, the conjugate calculation demonstrates transitional variations in the blade temperature, which are essential for life evaluation of the blade, and clarifies the thermal behaviors of the blade in start-up and shutdown processes.
\end{abstract}

Key Words: Gas Turbine, Conjugate Heat Transfer, Rotor Blade, Ribbed Cooling Passage

\section{1. 緒 言}

コンバインドサイクル発電プラントは, 高温のガス タービンにより, 高い熱効率と出力密度を有し, 負荷 変動への対応が比較的容易であるなどの利点から, 火 力発電の主要な設備となっている. 一方で, 高温とな るガスタービン内部で使用されるタービン翼や燃焼器 などの高温部品には超合金が用いられ，高性能かつ複 雑な冷却構造を備えるために単価が高く, 頻繁な交換 ／補修により，プラント保守コストを増大させる原因 となっている. 現状では, 高温部品の寿命について明 確な評価基準はなく，ガスタービンユーザはコスト低 減の観点から寿命延伸に向けた取り組みを行っている.

ガスタービン翼の寿命評価には, 運転条件に応じて 変化する翼温度分布を把握することが不可欠である. 翼温度分布は, 要素試験あるいは翼まわりの CFD 解析 による翼面熱伝達率に基づき, 熱伝導解析により求め る(1)ことが通例であるが，要素試験の条件は，実機環 境と大きく異なることが多い. 翼まわりの CFD 解析に ついても, 内部から冷却されるガスタービン翼とは異 なる, 何らかの熱的境界条件を翼外面に仮定する必要 があるなど，対応すべき熱的環境が苛酷であるにも関 わらず熱伝達の予測は困難である.

* 原稿受付 2006 年 6 月 30 日.

*1 正員, (財) 電力中央研究所 (焉 240-0196 横須賀市長坂 2-61).

E-mail : tosihiko@criepi.denken.or.jp
こうした問題のため, 進展する CFD 技術を背景に, ガスタービン冷却翼まわりの熱流動，翼構造材部の熱 伝導, および内部冷却を連成させた伝熱解析が温度評 価手法として検討されており，これまでにいくつかの 報告(2)(6)がなされている. しかしながら, 既往の報告 では, ほとんどが内部冷却に単純な平滑流路を仮定し ており, 近年のガスタービンで一般的に用いられる, リブなどの乱流促進体付き流路による冷却構造を想定 した例は極めて少ない，加えて，解析結果と計測結果 を比較した公表例はほとんどなく, 実際にガスタービ ンの冷却翼の評価に適用可能であるとは言い難い.

以上の観点から, 本研究では, これまで公表例の極 めて少ない，リブ付き流路によるガスタービン冷却動 翼の 3 次元連成伝熱解析を行った. 解析結果を翼の材 料組織から推定される温度と比較, 検証し, 翼の寿命 評価に不可欠なガスタービンの起動/停止過程の翼温 度分布の変化を明らかにした.

\section{2. 記 号}

c :翼弦長, $\mathrm{m}$

$D \quad$ :冷却流路の等価直径, $\mathrm{m}$

$e \quad$ :リブ高さ, $\mathrm{m}$

$e^{+} \quad$ : 粗さレイノルズ数, $(e / D) R e_{D}\left(f_{r} / 2\right)^{1 / 2}$

$f \quad$ :摩擦係数

$G \quad$ :熱伝達に関する粗さ関数

Gc : 冷却空気流量割合(ガスタービン流入空気 
量に対する), \%

$H, W$ : 泠却流路断面の高さおよび幅, $\mathrm{m}$

$h$ :熱伝達率, $\mathrm{W} /\left(\mathrm{m}^{2} \mathrm{~K}\right)$

$k \quad$ :乱流の運動エネルギー

$L E, T E$ :前縁および後縁

$l \quad$ :乱流変動の長さスケール, $\mathrm{m}$

$\mathrm{Nu} \quad$ :Nusselt 数 $=h \mathrm{c} / \lambda$

$\mathrm{Nr}$ : ロー夕回転数 $\mathrm{rpm}$

$O P$ :ガスタービン出力

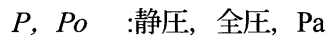

$p \quad$ :リブのピッチ, $\mathrm{m}$

$q \quad$ :熱流束, $\mathrm{W} / \mathrm{m}^{2}$

$R \quad$ : 運動量輸送に関する粗さ関数

$R L \quad$ : : 定格

$H L \quad$ :負荷 $50 \%$

$I G, E X$ :点火, 消火

$P I, P O$ :並列(電力系統への接続), 解列(並列解除)

$R e \quad$ :翼まわりの Reynolds 数

$R e_{D} \quad$ :冷却流路内の Reynolds 数(等価直径基淮)

$S \quad$ :翼面に沿う前縁から後縁までの距離, $\mathrm{m}$

$s \quad$ :翼面に沿う前縁からの距離, $\mathrm{m}$

St :Stanton 数

$T, T o \quad$ :温度(静温)および全温，K

$\Delta T \quad$ :温度差, $\mathrm{K}$

$t, \Delta t \quad$ :時刻および時間間隔， $\mathrm{s}$

$\alpha, \beta \quad$ :翼外面熱伝達率相関式の指数

$\lambda \quad$ :熱伝導率, $\mathrm{W} / \mathrm{mK}$

$\nu, v_{\tau} \quad$ :動粘性係数および渦動粘性係数, $\mathrm{m} 2 / \mathrm{s}$

添え字

air : :縮機流出あるいは流入空気

$b w, c w$ :翼外面および泠却流路面

$b w a, c w a$ :翼外面平均および泠却流路面平均

$c a$ :内部冷却流路入口平均值

$g, g a$ :翼まわり流れ, およびその流入境界平均

$\max \quad$ :最大

$P S, S S$ :圧力面および負圧面

$r \quad$ 冷却流路のリブ設置面

ref :基準条件

Start, Stop : 起動過程, および停止過程

* $\quad$ :無次元時間

\section{3. 数 值 解 析}

数值解析は, 翼まわりの熱流動および翼構造材部の 熱伝導の 3 次元熱流動解析に, 熱流体解析コード FLUENT(Fluent. Inc)を用い，これに 1 次元の熱収支計 算コードによる翼内部冷却の解析を組み合わせた.

3・1 解析対象 図1に, 対象動翼面の解析要素の 一部を示す. 解析対象は, 発電用大型ガスタービン初 段動翼を模擬し,動翼列内の翼一枚について解析した. 翼端とケーシング間のクリアランスは, 翼高さの $0.5 \%$ を設けた. 内部冷却流路(2)-(3)-(4)および(5)-(6)-(7)は, 四

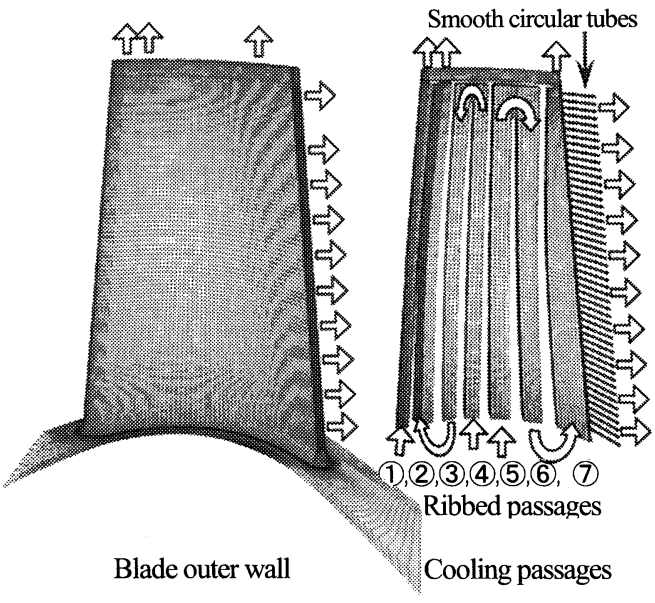

Fig. 1 Surface mesh and cooling flow of the blade

辺形断面のサーペンタイン冷却流路であり, 前縁部流 路(1)み翼外形状に沿つた丸みのある三角形に近い断 面をもつ. 流路(1)〜7)内部には, 熱伝達促進のために 翼外面に対する面に, 翼高さ方向に周期的なリブが設 置される. 後縁部には流路(7)と後縁を繋ぐ円管(滑面) 流路が設けられ，冷却空気は，翼根(流路(1)，(4)，(5) から流入し, 翼端, および後縁部の円管流路を通り翼 外に流出する.

3・2 解析方法 翼まわりの熱流動については, 翼 まわり, および後縁部の円管冷却流路内部までを 3 次 元解析領域に設定した. 数値解析では, 非定常圧縮性 粘性流れを仮定し, Reynolds 平均 Navier-Stokes(RANS) 方程式を解き, 理想気体の状態式を適用した. 乱流モ デルには, Spalart \& Allmaras の 1 方程式モデル(以下 SA モデル) (7)用い, 乱流熱流束の評価には, 乱流プ ラントル数を一定(0.85)とした代数モデルを用いた.な お, SA モデル(7)には, 主に翼端・翼根近傍における 2 次渦領域での確度を考慮して生成項の修正 ${ }^{(8)}$ を施した ものを用いた. 解析には, 動翼の回転角速度で移動す る相対座標系を用い, 座標の回転による見かけの体積 力は RANS 方程式の生成項として考慮した. 翼構造材 部では, 上記 RANS 方程式より, 運動量の寄与を除外 したエネルギー方程式(非定常熱伝導方程式)を解いた. 以上の支配方程式の離散化は, 非構造格子上で, 有限 体積法に基づく空間 2 次精度を用い,解法にはSIMPLE 法, 時間進行に 1 次陰解法を適用した.

解析要素は 6 面体要素および 3 角柱(プリズム)要素 を,壁面での直交性に留意して適用した. 解析要素は, 翼まわり(流体部)に $1,226,729$, 翼構造材部(固体部)に 294,811, 総数 $1,521,540$ とした. 翼面に隣接する流体 
部要素中心と壁面間の距離は $y^{+} \approx 1$ とし, 流体部と 固体部の要素は, 固体壁面上でノードを一致させた.

リブ付き内部冷却流路(1)〜 (7)内は, 乱れ度が高く, 非等方性の強い乱流場のため, 3 次元解析でも熱伝達 の予測確度を得るには，リブ形状を再現した大規模な 解析を要し, 前処理も大きな労力を要する. さらにリ ブ間の熱伝達率分布の影響は, 高温となる翼外面では 拡散するため, 本報においては, 内部冷却の評価にリ ブによる伝熱促進を考慮した相関式による 1 次元解析 を行った. これにより流路面のリブを解析要素から省 き, 形状変更に対して迅速な対応を可能とした.

ここで, リブ付き内部冷却流路における本 1 次元解 析は, 各翼高さ位置でのバルク温度, 流路面の熱伝達 率, および流路の圧力損失を計算し, 3 次元熱流動解 析に与える. リブ付き流路面の摩擦係数および熱伝達 率は, 運動量輸送および熱伝達に関する粗さ関数 $R$,

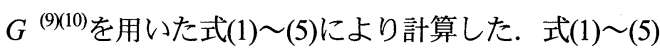
では, 流路(2)〜(7)を矩形流路と仮定し, ·前縁部流路(1) を円管で近似しているが，いずれも対応する流路に応 じて, リブによる閉塞率, 周期リブのピッチならびに 高さ, および流路内レイノルズ数が考慮される.

$$
\begin{aligned}
f_{r} & =\frac{2}{\left[R-2.5 \ln \frac{2 e}{H}-X\right]^{2}} \\
S t_{r} & =\frac{f_{r} / 2}{1+\sqrt{f_{r} / 2}[G-R]} \\
X & =3.75 ; \quad \text { Passages (1) } \\
X & =2.55 ; \quad \text { Passages (2) (7) }
\end{aligned}
$$

粗さ関数 $R, G$ は以下の相関式に拠る. 流路(2) (7)のリ ブ設置面については, 著者らによる, 矩形流路に関す る実験およびLES に基づく次式(6)(11)を用いた.

$$
\begin{aligned}
& R=(p / e / 10)^{0.35}[-32.2(e / W)+4.97] \\
& G=4.39\left(e^{+}\right)^{0.268}
\end{aligned}
$$

円管により近似する流路(1)は,次式(9)により算出した.

$$
R=0.95(p / e)^{0.53}, G=4.50\left(e^{+}\right)^{0.28}
$$

流路の平滑面については, 熱伝達に Kays と

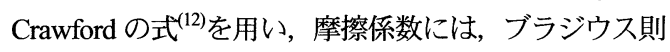
を用いた. ただし, 本研究では, リブおよびサーペン タイン流路の $180^{\circ}$ 曲がり部による熱伝達率分布の変 化, 流路の回転による影響を考慮していない. 今後さ らに予測確度向上に関して, 解析手法を高度化すべき 余地がある.

$3 \cdot \mathbf{3}$ 解析条件 基本条件として図 2 に示すガス夕 ービンの DSS( Daily Start and Stop) 運転時の起動／停
止過程を模擬した運転曲線を用いた，図は，運転曲線 (圧縮機流入空気量 $G_{a i r}$, 圧縮機吐出空気温度 $T_{a i r}$, 夕 一ビン入口ガス温度 $T o_{g a}$, ロー夕回転数 $N r$, いずれ も定格条件で正規化)を示す. 横軸の時間 $t^{*}{ }_{\text {start }}, t^{*}$ Stop は, (a)起動過程では, 点火(IG)から定格(RL)条件まで の時間により，(b)停止過程では, 定格(RL)条件から消 火(EX)までの時間で正規化した無次元時間である.

本研究では, 既報告 ${ }^{(4)}$ と同様に流れの小スケ一ル変 動(例:周期的に通過する上流静翼後流など)については, 解析時間刻みを十分大きく設定することにより，アン サンブル平均的に取り扱った. 過渡解析の時間刻みは, 起動過程について $\Delta t^{*}{ }_{\text {sart }}=6.41 \times 10^{-3}$, 停止過程について は，それぞれ $\Delta t^{*}{ }_{\text {stop }}=1.75 \times 10^{-2}$ とした。

表 1 には, 境界条件の設定項目を,それぞれの定格条 件とともに示す．これらの設定項目は，運転曲線を基

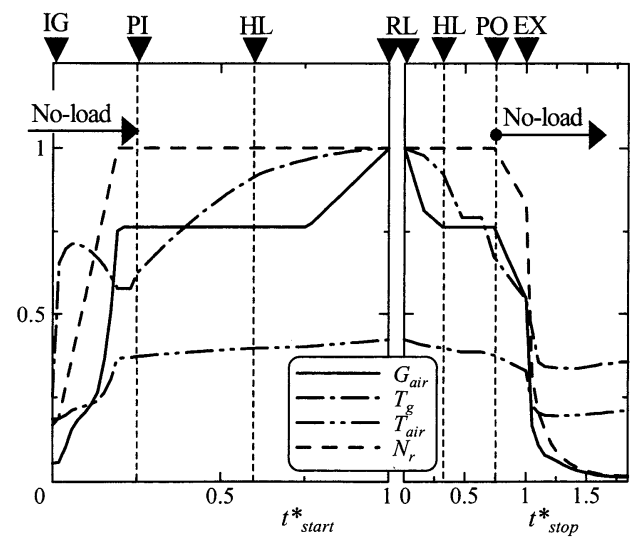

Fig. 2 Simulated characteristic diagrams

Tablel Items of analytical condition and their rated values (a) 3-D calculations around the blade

\begin{tabular}{|l|l|c|c|c|}
\hline \multirow{2}{*}{ Inlet } & \multicolumn{2}{|l|}{ Mass flow rate per blade } & $\mathrm{kg} / \mathrm{s}$ & 3.87 \\
\cline { 2 - 5 } & Total temperature & Ave. & $\mathrm{K}$ & 1561.2 \\
\cline { 2 - 5 } & Turbulence Intensity & $\%$ & 5.0 \\
\hline Outlet & Static pressure & $\mathrm{Pa}$ & $8.01 \times 10^{5}$ \\
\hline $\begin{array}{l}\text { Blade } \\
\text { root }\end{array}$ & $\begin{array}{l}\text { Temperature } \\
\text { Thermal resistance under } \\
\text { the wall is taken into account }\end{array}$ & $\mathrm{K}$ & 660 \\
\hline
\end{tabular}

(b) 1-D calculations in the ribbed passages

\begin{tabular}{|c|l|c|c|}
\hline Inlet & $\begin{array}{l}\text { Mass-flow-rate ratio of cooling } \\
\text { air,Gc }\end{array}$ & $\%$ & 2.75 \\
\cline { 2 - 4 } & Temperature, Tc & $\mathrm{K}$ & 660 \\
\cline { 2 - 4 } & Static pressure & $\mathrm{Pa}$ & $1.45 \times 10^{6}$ \\
\hline
\end{tabular}

Table 2 Variations in the blade wall temperature $\Delta T$, due to the cells-increment from the primary case

\begin{tabular}{|l|c|c|}
\hline & $\Delta T, K$ & $\Delta T /\left(T_{g a}-T_{c a}\right) \times 100 \%$ \\
\hline Span $80 \%$ average & 0.1 & 0.02 \\
\hline Span 50\% average & -2.4 & -0.3 \\
\hline Span 20\% average & -4.8 & -0.7 \\
\hline
\end{tabular}


に過渡的に与えた. 翼まわりへの流入境界における夕 一ビン周方向分布は，解析時間刻みを考虑して一様と し, 温度分布は平均ガス温度を基準に, プロファイル ファクター $\left(T_{\text {gmax }}-T_{g a}\right) /\left(T_{g a}-T_{c a}\right) \times 100=5 \%$, 翼高さ の $70 \%($ 翼端側)の位置で極大となる翼高さ方向の放物 線分布を与えた。流入する乱れは, SA モデルクのの輸送 量である

$$
\widetilde{v}=\sqrt{k} l
$$

によって与光た.ここで, 長さスケール lは, ガスパ 不高さ $L$ を用いて, ニクラーゼの式における混合長さ の最大值 0.07 により $l=0.07 L$ とした. 乱流運動エル ギー $k$ は, 乱流強度 $(5 \%$ 一定として仮定)より求めた.

翼間は周期条件とし,翼根およびハブ壁面については, 翼取りつけ部の熱伝導を模擬すべく，壁面下に熱抵抗 を付加した等温条件を課した. 翼の内部冷却は, 実機 では圧縮機からの抽気により，解析条件には，図 2 に 示す圧縮機流入空気量に対して，表 1 (b)に示す一定割 合が内部冷却に用いられるものとした. 泠却空気温度, 庄力は圧縮機吐出条件に基づいて与えた.

翼まわりガスの物性(粘性係数 $\mu$, 熱伝導率 $\lambda$, 比熱) は, 燃焼ガス各成分の物性を組成に基づき補間し, 翼 構造材の物性(熱伝導率，比熱)は, Ni 基超合金の測定 值 (13)を用いた、いずれも温度依存性を多項式近似によ り考慮し，局所温度に基づき評価した。

表 2 には, 解析要素数による影響を示す. 最も翼温 度が高い定格(RL)条件について, 前述の解析要素に対 して，翼まわりの壁面近傍を重点的に，解析要素を増 加させた解析(要素数 2,040,409, 約 66\%増)を行ったが, 両解析結果に有意な差異は認められなからた。

\section{4. 解析結果および考察}

$4 \cdot 1$ 定格条件における結果 図 3 には，定格運転 条件における翼まわりの比エンタルピー分布および絶 対渦度分布(タービン軸方向に垂直な面)を示す. 翼端 側およひ翼根側の 2 次渦(漏れ渦および流路洞)忙, 既 研究(14)による動翼まわりの流れ模様と定性的に一致 する.翼端側の分布からは, 本解析対象の冷却翼では, 翼端より翼外に放出される冷却空気が, 翼端側の 2 次 渦および後流渦に連行され，エネルギ一の低下が顕著 な領域が生じることがわかる.

図4には，(a)解析結果による翼外面温度分布を，(b) 実機翼の外観写真とともに示す．これらの比較から， (a)解析結果の高温域は, (b)における翼端後縁付近およ び負圧面の前縁近傍における高温酸化による損傷によ く符合しており，実機翼の状態を再現している.
さらに，表 3 および図 5 には，定格条件について， 本連成伝熱解析による翼外面温度を，対象とする実機 翼の材料組織分析により推定した温度と比較する. 図 5 には本研究々同様の材料組織分析結果 ${ }^{(15)}$ を併せて示 す. 表 3 には各翼高さの平均温度を示し, 図 5 は局所 温度分布(実線で定格条件を示す)を示す.図 5 の各温度 分布は，それぞれの時刻について，解析結果による翼 外面平均温度を除した温度を示しており, 材料組織に よる推定温度は，定格条件の解析結果による翼外面平 均温度を除した值である，材料組織による翼温度の推 定は, 翼外面の耐腐食コーティングの組織観察に基づ

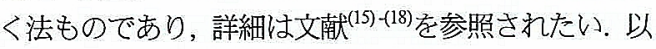
下では概要のみを示す.

本解析が模擬する夕ービン冷却翼の外表面には，熱

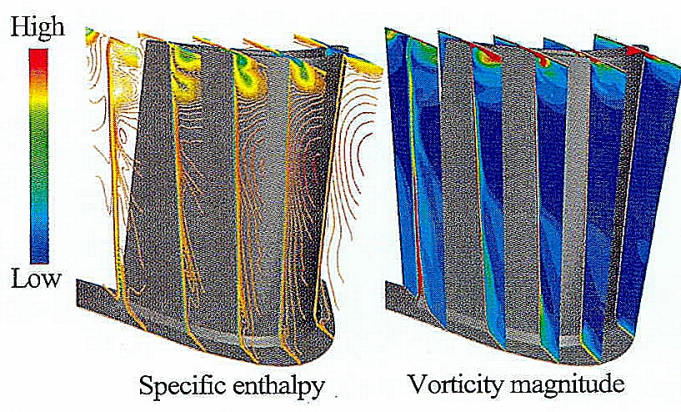

Fig 3 Distributions of specific enthalpy and vorticity magnitude around the blade (suction side view)
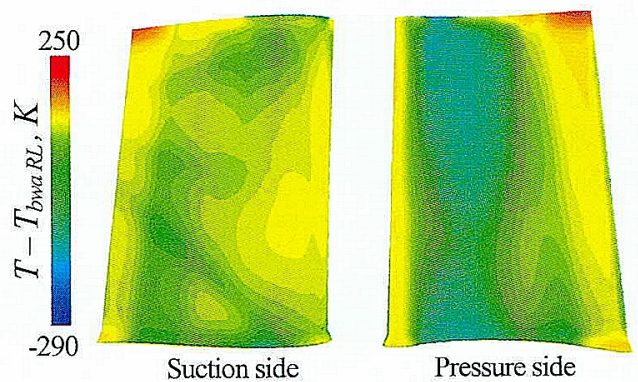

Pressure side

(a) Predicted local temperature on the blade

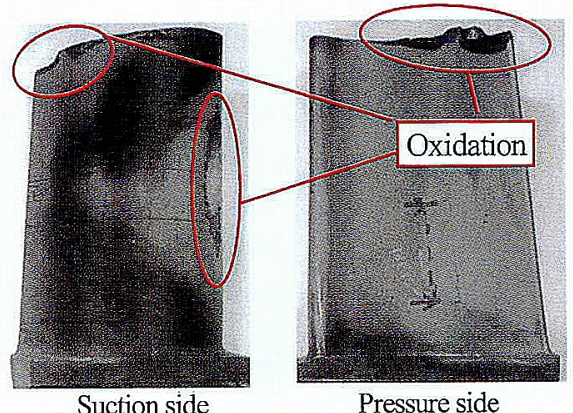

Suction side

Pressure side

(b) Exterior condition of a blade (photos)

Fig 4 Comparison between prediction and a actual blade 
物性が基材とほぼ同一の耐食コーティングが施工され ている.この耐食コーティングは, ガスタービンの運

Table 3 Temperature difference in the prediction from the estimation with the destructive test

\begin{tabular}{|l|l|}
\hline Span $80 \%$ average & $-0.7 \mathrm{~K}$ \\
\hline Span $50 \%$ average & $-5.6 \mathrm{~K}$ \\
\hline Span $20 \%$ average & $-3.5 \mathrm{~K}$ \\
\hline
\end{tabular}

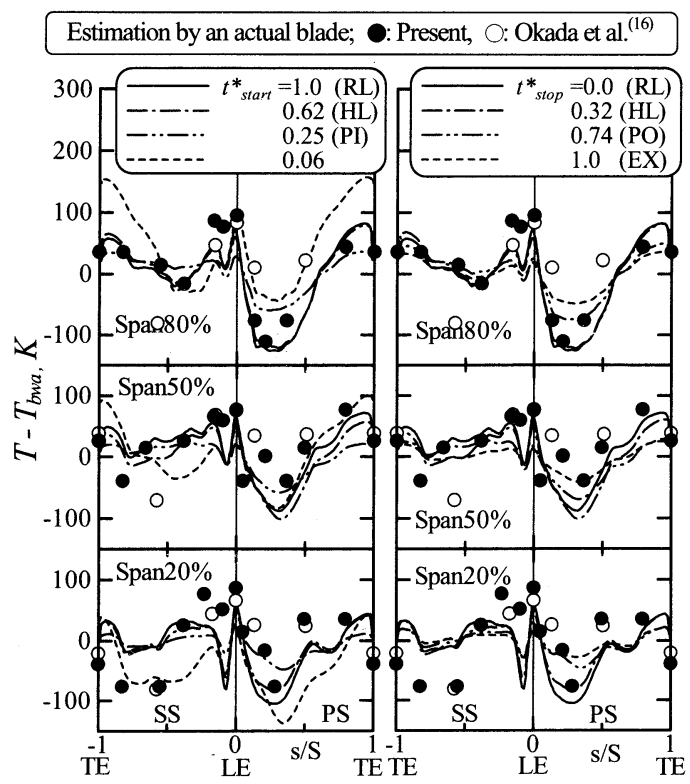

Fig 5 Local temperature profiles on the blade

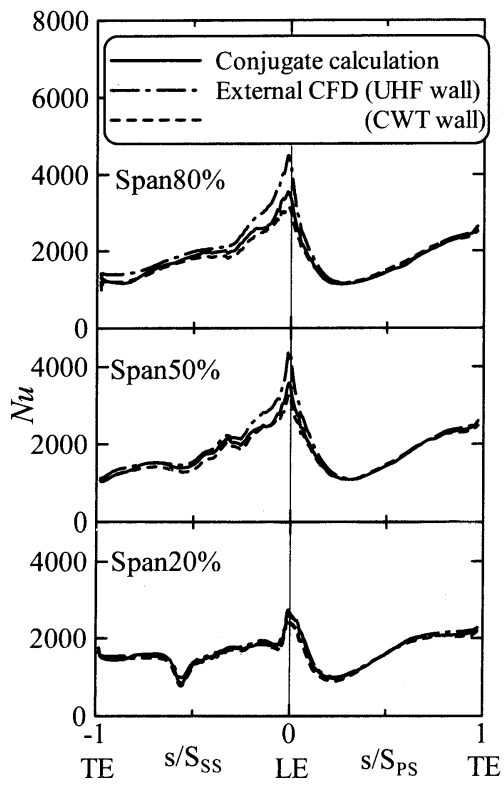

Fig 6 Discrepancy in local Nusselt number on the blade
転中に劣化し, 基材との間にアルミ原子の拡散層(以下 界面拡散層)が成長する. この拡散層の厚さは, 高温ガ スに曝された時間(運転時間)の平方根に比例して増加 し, 成長率はアレニウスの関係による温度依存性が確 認されている ${ }^{(15)-(17)}$. 本研究では, 模擬試験片の時効試 験により取得した界面拡散層厚さの成長挙動に関する 校正曲線、およびタービン冷却翼より切り出した部位 のアルミ拡散層厚さを計測することにより, 翼の局所 温度を推定した. 本温度推定方法における誤差の参考 として, 同一運転時間を経た翼の, それぞれ同じ位置 の拡散層厚さのバラツキはおよそ $20 \%$ あ, この結果

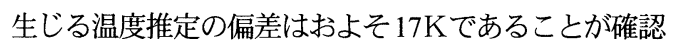
されている ${ }^{(16)}$.

表 3 より, 本解析は, 翼平均温度を僅かに低く予測 する傾向があるが，ほぼ一致する結果を得た. 図 5 に 示す温度分布についても, 本解析は, 破壊試験に対し て良好な予測結果を示し, 前縁, 負圧面側の前縁近傍, および後縁近傍など, 寿命の上で重要な高温部におい て定量的一致が見られた.

図 6 では, 定格運転条件における, 翼外面の局所 Nusselt 数分布(流入条件も基づく)について, 本連成伝 熱解析と翼まわりのみの CFD 解析を比較する. 翼まわ りのみの CFD 解析は, 連成伝熱解析の翼まわりの解析 を分離して実行したものであり, 翼外面の熱的条件は, 実機翼との隔たりが少なくなるよう, 連成伝熱解析よ る平均值に基づく等温(CWT)条件および熱流束一様 (UHF)条件を課した. その結果, 連成伝熱解析による Nusselt 数は, 両 CFD のみの解析結果の間のレベル(両 者の差異の大きい, 翼高さ $80 \%$ 前縁などで明瞭)を示 し, 翼外面温度の近い CWT 条件による解析と比較的 一致する結果となった. 連成伝熱解析と他解析の差異 は, 翼外面の熱的条件により壁面近傍温度および熱物 性值の評価が異なるためであり, 連成伝熱解析の場合 には, 翼外面の条件を考慮する必要はない.

$4 \cdot 2$ 起動・停止に伴う䦔温度分布の变化 図 5 に はまた, 起動/停止過程の翼外面温度分布を示す. 起 動過程では, 点火直後の急激なガス温度上昇により, 翼周方向および翼高さ方向ともに大きな温度勾配が生 じる. 一方で, 停止過程には時間とともに一様な分布 となる. 並列以降および解列以前の運転時には, 温度 分布形状に変化は小さく, 特に定格(RL)条件および負 荷 50\%(HL)時は, ほぼ相似となる. 以上のように, 本 解析により, 翼の熱応力/クリープ解析をはじめとし た寿命評価に不可欠, かつ実測が困難な起動/停止に 伴う翼温度分布が得られた.

図7(a),(b)には，それぞれ起動/停止に伴う翼面(翼 


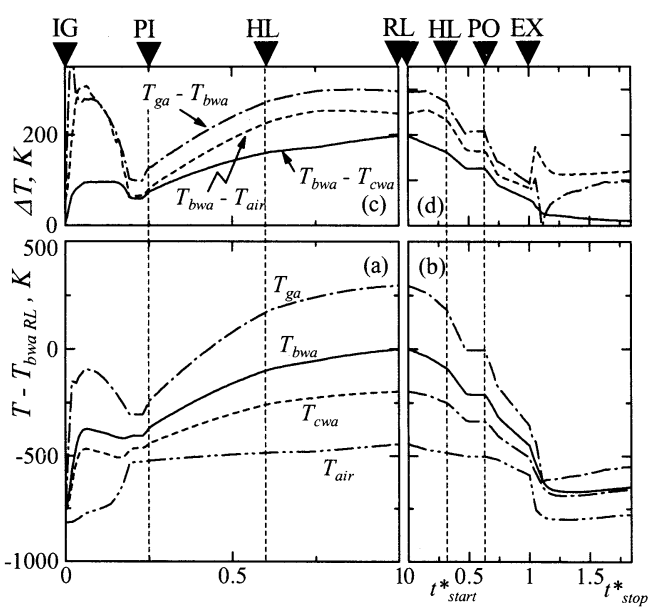

Fig 7 Variation of the wall average temperature

外面および冷却流路面)平均温度の変化, および図 7(c),(d)には, 翼面間の平均温度差, および翼面と流入 ガス, ならびに冷却空気の平均温度差の変化を示す. 図 7(a),(b)では, いずれの翼面平均温度もガス温度およ び圧縮機吐出空気温度の影響を受けつつ時間とともに 推移し, 定格(RL)条件において, 両平均温度および温 度差ともに最大となる. 起動過程の点火直後, および 停止過程の消火直後には, 大きな温度変化が生じ, こ れら無負荷運転時には, 非定常的な熱移動が顕著であ る. また, 図7(c),(d)からは, 並列から解列までの運転 における翼の熱移動には, 翼外面からの熱負荷の影響 が最も大きく, 本対象翼のように高い冷却効率を有す る夕ービン冷却翼の温度推定には, 特に, 翼外面熱伝 達率に対する予測精度が重要であることを確認できる.

\section{5. 結 言}

発電用大型ガスタービン初段のリブ付き流路によ る冷却動翼を対象に, 3 次元連成伝熱解析を行った. 解析に翼の冷却構造を反映し, 解析方法には, 翼まわ りの RANS 解析, 翼構造材部の熱伝導解析および内部 冷却解析を連成させた. 内部冷却解析には, 著者らを 含む既研究の伝熱相関式を用い, リブ等の流路内形状 の変更に対して迅速に対応可能な解析方法を構築した. 本解析方法により, タービン冷却翼の寿命評価に不 可欠, かつ, 実測が困難なガスタービンの起動から停 止に至るまでの翼温度分布が得られ, その特徴的な挙 動が明らかとなつた. 冷却翼の熱的環境を適切に模擬 した結果として, 定格条件について予測された翼外面 の高温領域は，実機翼の損傷部位に良く対応するとと もに，実機翼の材料組織を基に推定した翼温度と良好 に一致した.
今後, 内部冷却などに対して、より精緻に評価する ことにより，さらに予測確度の向上が期待できる.

\section{文献}

(1)Gas Turbine Society of Japan ed., Increasing Turbine Inlet Temperature and Cooling Technology of a Gas Turbine,(1997), Gas Turbine Society of Japan.

(2)Bohn, D., Bonhoff, B., Schonenbom, H., Combined Aerodynamic and Thermal Analysis of a High-Pressure Turbine Nozzle Guide Vane, Proc.Yokohama I.G.T.C., Vol.1(1995), pp. 35-39.

(3)Han, Z. X., Dennis, B. H., and Dulikravich, G. S., Simultaneous Prediction of Extermal Flow-Field and Temeperature in Intemally Cooled 3-D Turbine Material, ASME Paper 2000-GT-253(2000).

(4)Takahashi, T et al., Thermal Conjugate Analysis of a First Stage Gas Turbine Blade, Trans. JSME, Vol.66, No.647, Series B(2000), pp.1772-1779.

(5)Takahashi, T. et al., Temperature Behaviour of a First Stage Bladein Start-up and Shut-down of a Gas Turbine, Trans. JSME, Vol.69, No.680, Series B(2003), pp.243-248

(6)Takahashi, T. et al, Numerical Analysis of Heat Transfer for Gas Turbine Hot-gas-path Parts 5th report, CRIEPIReport, W03011(2004)

(7)Spalart, P. R. and Allmaras, S. R., A one-equation turbulence model for aerodynamic flows, ALAA paper, 92-0439(1992).

(8)J.Dacles-Mariani, G.G.Zilliac, J.S.Chow and P.Bradshaw. Numerical:Experimental Study of a Wingtip Vortex in the Near Field. AIAA J.,33(9)(1995):pp.1561-1568,

(9)Webb, R. L., Eckert, E. R. G. and Goldstein, R. L, Heat Transfer and Friction in Tubes with Repeated-Rib Roughness, Int. J. Heat Mass Transfer, 14(1971)pp.601-617.

(10)Han,J.C., Heat Transfer and Friction in Chamels with Two Opposite Rib-Roughened Walls, Trans. ASME, J. Heat Transfer, 106(1984), pp.774-781.

(11)Watanabe, K. and Takahashi, T., LES and measurement of heat transfer and flow in rectangular channels with crossed angled ribs, Trans. JSME, Vol.71, No.705, Series B(2005),pp.1459-1464.

(12)Kays, W. M. and Crawford M. E., Convection Heat and Mass Transfer (2nd ed),(1980), p.243, MoGraw-Hill.

(13)Fujii, T. and Takahashi, T., Estimation of Thermophysical Properties of Coating Layers for Gas Turbine Hot Parts, CRIEPIReport, W97017(1998)

(14)Sieverding, C. H., Recent Progress in the Understanding of Basic Aspects of Secondary Flows in Turbine Blade Passages, Trans. ASME J. Eng. Gas Turbines and Power, 107(1985), pp248-257.

(15)Okada, M. et al, Examination of Temperature Estimation and Alminum-content Prediction for a Gas Turbine Coating, CRIEPI report, W01022(2002)

(16)Okada, M. et al, Temperature Estimation and Prediction of Aluminum-Content by Means of Microstructural Change in Gas Turbine Coatings, J. Soc. Material Science, Vo.54,No.3(2005), pp.257-264 (17)Srinivasan,V., Chenuvu, N. S., Carr, T. J. and O'Brien, C. M., 1995, Materials and Marufacturing Process,10(1995), p955. (18)Viswanathan, R., Cheruvu, N. S. and Chan, K. S., Coatings for Advanced Large Frame Comstion Turbines for Power Generation, $A S M E$ Paper GT2003-38105(2003). 